\title{
Analisis Penerapan Project Based Learning Approach dalam Pembelajaran On-Line dimasa Pandemi Covid 19
}

\author{
Tri Kurniawati' ${ }^{1}$, Sahrawi $^{2}$ \\ 1,2IKIP PGRI Pontianak, Indonesia \\ E-mail:awihasanah@gmail.com
}

\begin{abstract}
Article Info
Article History

Received: 2021-11-15

Revised: 2021-11-28

Published: 2021-12-10

Keywords:

Project Based Learning;

English Language

Learning;

Online.

Abstract

Project based learning is an approach that focus on students' activity as centered in the class. This research is in the form of qualitative where second semester students as sample choosen purposively. The purposes of this research are to know the students' perception and the effect of the implementation of project based learning approach on online public speaking class. The data were collected by interview, observation, and documentation. There are 12 students participated in this study. The result of the study showed that the students' respons is potiitif toward the use of project based learning approach. They could learned by doing. The implementation of this approach made students motivated in joining the class, their skill improved in the term of autonomous learning, organizing ideas or tasks, teamworrk, sharing ideas to other people or communication, and problem solving. However there are several obstacles that must be minimized namely the large cost of kuota, the unstable networks, even the bored feeling when they stare the monior of HP or laptop through the lesson.
\end{abstract}

\begin{tabular}{l}
\hline Artikel Info \\
\hline Sejarah Artikel \\
Diterima: 2021-11-15 \\
Direvisi: 2021-11-28 \\
Dipublikasi: 2021-12-10
\end{tabular}

Kata kunci:

Pembelajaran Berbasis Proyek;

Pembelajaran Bahasa Inggris;

On line.

\section{PENDAHULUAN}

Pendekatan yang digunakan dalam mengajar memiliki peran penting dalam mencapai tujuan pembelajaran yang efektif. Penggunaan pendekatan dalam mengajar yang tepat dapat memberikan hasil belajar yang maksimal dimana proses belajar mengajar juga dapat menjadi lebih menarik. Dengan demikian, penting bagi tenaga pendidik untuk mengetahui berbagai macam pendekatan pengajaran yang sesuai dengan kebutuhan didalam kelas agar tujuan dari pembelajaran dapat dicapai secara maksimal, seorang pengajar harus bisa menentukan pendekatan yang paling sesuai dengan situasi, kondisi ruang kelas dan keadaan peserta didik agar efektifitas proses belajar mengajar dapat tercapai. Suatu pendekatan dalam mengajar dapat dikatakan efektif ketika dapat memberikan hasil yang sesuai dengan tujuan. Dengan kata lain, semakin baik dan tinggi hasil dari pembelajaran maka dapat dikatakan semakin efektiflah suatu pendekatan mengajar yang digunakan. Tetapi hal lain yang menjadi pertimbangan dalam pemilihan suatu pendekatan yaitu penggunaannya juga harus efisien. Efisien artinya pendekatan yang digunakan dalam kelas tidak terlalu menguras tenaga, biaya, maupun waktu sehingga pelakssanaannya dapat dengan mudah diterapkan oleh setiap pengajar.

Project based learning merupakan pemberian tugas atau proyek yang kompleks sesuai dengan tema dari materi yang sedang didiskusikan 
dimana peserta didik harus memecahkan masalah yang diberikan, mengambil suatu keputusan sesuai dengan durasi waktu yang telah ditentukan sebelumnya sehingga mereka dapat menghasilkan suatu produk. Pendekatan ini sudah lama dikenal dalam dunia pendidikan (Fauziati, 2014:166). Proses pembelajaran difokuskan pada kegiatan peserta didik dalam menerapkan kemampuan mengananlisis, membuat, dan mempresentasikan hasil atau produk baik berupa karya tulis, teknologi, maupun karya seni yang diperoleh berdasarkan pengalaman nyata sehingga peserta didik dapat melatih diri dalam merencanakan, melaksanakan, menampilkan, dan melaporkan kegiatan sesuai dengan rencana yang telah disusun. Penerapan pendekatan project based learning menjadi lebih efektif ketika diimplementasikan pada situasi dan materi yang tepat serta didukung oleh faktor lain yang baik seperti penggunaan media online. Penggunaan pendekatan project based learning secara online lebih mempermudah seluruh peserta didik dalam mengikuti proses pembelajaran.

Pembelajaran online yang juga dikenal dengan e-learning merupakan proses pengajararn yang menggunakan jaringan internet dan berbasis digital. Dalam penggunaan online learning, proses belajar mengajar dapat dilaksanakan kapan saja dan dimana saja sehingga memudahkan para pendidik dan peserta didik dalam melakukannya. Dewi (2020:56) menjelaskan bahwa dengan adanya pembelajaran online maka peserta didik memiliki keleluasan waktu belajar, dapat belajar kapanpun dan dimanapun. Pendapat lain juga disampaikan oleh Isman (2016:587) mengatakan bahwa pembelajaran daring adalah suatu proses pembelajaran yang memanfaatkan jaringan internet dalam melaksanakan suatu proses belajar mengajar. Pelaksanaan online learning dapat dilakukan dengan menggunakan HP, komputer, maupun alat elektronik lainnya. Pelaksaan pembelajaran online juga dapat menjangkau secara luas dalam waktu bersamaan sehingga dapat diikuti oleh jumlah yang banyak. Disamping itu juga dapat melakukan pembaharuan data atau materi, menyimpan, dan membagikan materi dalam waktu yang relatif singkat dan mudah.

Proses belajar dapat dilakukan dari jarak jauh oleh setiap orang dengan menggunakan internet. Hal ini juga dapat dilaksanakan secara interaktif sehingga dapat dikatakan sebagai pembelajaran konvensional yang digabungkan dengan format digital melalui teknologi internet. Menurut
Harjanto dan Sumunar (2018) (dalam Jamaludin dkk, 2020:3) pembelajaran daring merupakan suatu proses transformasi pendidikan dari konvensional berubah ke dalam bentuk digital sehingga memiliki tantangan dan peluang tersendiri. Pemilihan pembelajaran online berawal dari penyebaran virus corona di dunia pada akhir tahun 2019 dan diawal 2020 virus ini masuk ke Indonesia sehingga pemerintah mengeluarkan kebijakan untuk melaksanakan pembelajaran secara online agar dapat memutus mata rantai penyebaran virus tersebut.

Penyebaran pandemi Covid 19 memiliki dampak negative dan positif terhadap tatanan hidup masyarakat dunia termasuk Indonesia. Penyebaran virus tersebut juga berdampak pada berbagai sector kehidupan seperti perekonomian, pariwisata, dan pendidikan. Salah satu sisi negativenya adalah masih banyak tempat atau sekolah yang belum siap untuuk melaksanakan pembelajaran online secara total dikarenakan fasilitas yang kurang memadai. Sementara dampak positif dari adanya virus corona ini adalah tersedianya berbagai macam flatform yang berkaitan dengan proses belajar mengajar secara online dan dapat diakses oleh semua pihak.

Oleh karena itu, penelitian ini penting untuk dilakukan agar memberikan informasi kepada berbagai pihak terutama pendidik sehingga dapat mengetahui efektifitas penggunaan pendekatan yang tepat dalam proses belajar mengajar yang dilaksanakan secara online. Dengan hasil penelitian, semoha dapat membantu para pengajar dalam mencapai tujuan pembelajaran dengan maksimal.

\section{METODE PENELITIAN}

Penelitian adalah penelitian kualitative deskriptif dalam bentuk studi kasus terhadap penerapan pendekatan mengajar project-based learning secara online dimasa pandemic dalam kelas Bahasa inggris khususnya di mata kuliah Public Speaking Kelas B Pagi semester II. Studi kasus dilaksanakan untuk investigasi secara menyeluruh dan detail. Sebagaimana Ari, Jacobs, Sorensen, \& Razavieh (2010: 454) mengatakan bahwa studi kasus dilakukan untuk menggali informasi secara mendalam. Peneliti menganalisis dan menyajikan secara nyata segala informasi yang diperoleh dari lapangan ketika pengajar menggunakan project based learning di dalam proses belajar mengajar, lokasi pelaksanaan penelitian ini adalah kampuas IKIPPGRI Pontianak, program studi Pendidikan 
Bahasa Inggris. Tempat penelitian ini berada di jalan Ampera, Kecamatan Pontianak Barat. Data dikumpulkan menggunakan interview, observasi, dan dokumentasi. Proses interview dilakukan antara pewawancara dengan orang yang diwawancai dalam menggali informasi (Richards \& Schmidt, 2010: 298). Sementara observasi dilakukkan untuk memperoleh informasi dari orang atau tempat yang diteliti secara langsung (Creeswell, 2012: 213). Data juga diperkaya dengan analisis dokumen. Given (2008: 24) mengatakan bahwa analisis dokumen adalah peneliti melakukan penggalian informasi terhadap tulisan dan dokumen secara fisik, tulisan tangan atau print out dan lainnya.

\section{HASIL DAN PEMBAHASAN}

Virus corona mulai masuk ke Indonesia pada awal tahun 2020 tepatnya pada bulan maret. Penyebaran virus corona menyebabkan proses belajar mengajar berubah menjadi serba online. Penyebaran virus ini memberikan dampak yang sangat signifikan pada seluruh sektor kehidupan termasuk dalam dunia pendidikan sehingga pemerintah khususnya kemendikbud mengeluarkan kebijakan agar proses belajar mengajar dilaksanakan secara online agar dapat memutus mata rantai dari penyebaran virus tersebut. Agar dapat mencapai tujuan pembelajaran secara maksimal meskipun pembelajaran dilaksanakan secara online, maka pendidik harus kreatif dalam mendesain materi dan memilih metode ataupun pendekatan mengajar yang tepat.

Pendidik harus tetap memaksimalkan hasil dari pembelajaran meskipun dilaksanakan secara daring agar esensi dan pengalaman dari belajar mengajar tetap dirasakan oleh peserta didik. Pendekatan project based learning merupakan salah satu pendekatan yang dapat digunakan dalam pembelajaran termasuk pembelajaran online. Penerapan pendekatan project based learning sebagai salah satu alternatif dalam mencapai tujuan pembelajaran dimana proses belajar mengajar dapat disesuaikan dengan kondisi pandemi. Pengajar menerapakan pendekatan ini dengan menggunakan berbagai platform seperti google classroom, whatapps, google meet, zoom, umeetme, dan lain lain. Pelaksanaan aktifitas kelas tersebut dilaksanakan secara mandiri oleh peserta didik. Sementaraa pendidik memantau jalannya kegiatan yang sedang berelangsung yang kemudian dilakukan penilaian terhadap hasil dari tugas mahasiswa. Tahap yang selanjutnya pengajar melakukan evaluasi dari kegiatan yang telah dilakukan. Setiap peserta didik memiliki tanggung jawab terhadap proyek yang telah dilakukan, oleh karena itu mereka berperan secara aktif dalam proses belajar mengajar.

Penggunaan pendekatan mengajar Project Based Learning secara online dalam masa pandemi memberikan dampak yang beranekak ragam dalam dunia pendidkan. Dalam penerapan pendekatan project based learning peserta didik dapat melakukan komunikasi atau mengerjakan tugas secara independen karena prinsip dari pendekatan ini adalah student-centered. Pendekatan project based learning dapat membantu peserta didik dalam meningkatkan kemampuan komunikasi, critical thingking, autonomous learning, dan problem solving sehingga kemampuan mereka dapat berkembang dengan baik. Kegiatan yang berlangsung didalam pembelajaran difokuskan pada peserta didik, sementara pendidik hanya sebagai fasilitator sehingga pendidik tidak memberikan informasi secara penuh di dalam kelas. Data yang dikumpulkan melalui wawancara, observasi, dan dokumentasi menunjukkan bahwa peserta didik memiliki motivasi yang tinggi dalam mengikuti pembelajaran. Mereka mau melakukan kerjasama dengan teman yang telah ditentukan sebelumnya oleh pengajar dalam menyelesaikan tugas. Mahasiswa juga langsung mengerjakan perintah atau tugas yang diberikan oleh dosen. Mereka juga mau mengungkapkan atau menyampaikan pendapat mereka secara langsung kepada dosen. Selama proses belajar mengajar berlangsung, sebagian mahasiswa juga cenderung bertanya jika ada materi yang belum jelas.

Peserta didik juga dapat mengembangkan kemampuan dengan serangkaian aktifitas dalam kelas seperti bekerjasama dengna teman yang lain, mengatur atau mempersiapkan materi yang akan di sampaikan di dalam kelas, serta dapat meningkatkan kemampuan presentasi. Proses belajar mengajar menjadi lebih menarik karena peserta didik melakukan tugas secara mandiri sehingga dapat memotivasi mereka untuk menyelesaikan secara maksimal. Dengan motivasi belajar yang tinggi maka tujuan dari pembelajaran menjadi lebih mudah dicapai.

Pendekatan project based learning merupakan suatu pendekatan dimana peserta didik menjadi pusat dari kegiatan dalam pembelajara sehingga dalam penerapan project based learning approach, para mahasiswa menjadi lebih aktif. Mereka menjadi terbiasa untuk menyampaikan pendapat, memberikan solusi kepada teman yang lain dalam menyelesaikan project yang diberikan 
oleh dosen. Meskipun dalam pelaksanaannya tidak dapat berjalan secara semaksimal pembelajaran yang dilakukan tatap muka secara luring (offline) karena tidak dapat dipantau secara langsung oleh pengajar. Disamping itu, mereka juga harus menatap ke layar kamera HP atau laptop sepanjang pembelajaran.

Pendekatan project based learning menjadi lebih efektif jika pengajar mengetahui kelebihan dan kekurangan serta cara untuk memaksimalkan pelaksanaan suatu pendekatan. Sama halnya dengan pendekatan yang lain bahwa project based learning juga memiliki kelebihan dan kekurangan. Pengajar harus bisa meminimalisir kekurangan agar proses belajar mengajar dapat berjalan secara efektif, penggunaan pendekatan project based learning membuat proses yang dilalui oleh peserta didik menjadi lebih bermakna karena mereka dapat berpartisipasi secara langsung dalam aktifitas kelas. Mereka dapat bekerja sambil belajar (learning by doing). Peserta didik juga menjadi lebih mandiri dalam menyelesaikan tugas sehingga kemampuan problem solving dan autonomous learning mereka juga berkembang dengan baik.

Penerapan pendekatan project based learning memiliki beberapa kendala yang harus diperhatikan oleh seorang pendidik agar bisa memaksimalkan proses belajar mengajar. Pendidik harus meminimalisir atau bahkan menghilangkan hambatan yang terjadi. Hambatan yang terjadi dalam penerapan pendekatan project based learning secara online yaitu kegiatan belajar mengajar yang berubah total menjadi serba online mengharuskan mahasiswa melakukan adaptasi. Cara belajar baru yang tidak pernah digunakan sebelumnya menjadi tugas yang harus diselesaikan oleh mahasiswa. Disamping itu, mahalnya kuota internet yang harus disiapkan oleh peserta didik juga menjadi beban tersendiri yang harus dipertimbangkan oleh semua pihak. Sebagian besar mahasiswa tidak memiliki wifi sehingga mereka harus membeli kuota untuk mengikuti perkuliahan yang di laksanakan secara online. Pembelajaran yang dilaksanakan secara online membuat mahasiswa pulang ke kampung halaman mereka dengan alasan ingin kumpul bersama keluarga untuk meminimalisir pengeluaran selama perkuliahan online. Sebagai efeknya adalah sebagian mahasiswa berada di pelosok sehingga mereka kesulitan dalam mencari jaringan yang stabil. Disamping itu juga, kekurangan atau keluhan yang dialami oleh mahasiswa adalah terkadang mereka merasa bosan karena harus menatap ke layar laptop atau HP selama pembelajaran berlangsung. Proses belajar mengajar juga memerlukan waktu yang lebih lama karena seringkali kendala teknis lainnya sering terjadi seperti terlambatnya mahasiswa gabung ke kelas online yang sudah disediakan, gangguan dari luar seperti keluarga yang sedang berada disamping mahasiswa saat mengikuti kelas. Syah (2020) mengatakan bahwa terdapat empat kendala yang dihadapi oleh dunia pendidikan di masa pendemi covid-19 yaitu: a) penguasaan internet; b) kurangnya sarana dan prasarana; c) terbatasnya akses internet; d) kurangnya dana.

Pendidik harus tetap menyajikan atau menfasilitasi proses pembelajaran agar tetap terlaksana secara maksimal. Salah satu caranya adalah dengan menggunakan suatu pendekatan yang tepat dalam mengajar. Pendekatan yang sesuai dengan kebutuhan peserta didik sehingga dapat mencapai tujuan pembelajaran secara maksimal. Pendidik harus bisa menganalisis dan menentukan pendekatan yang paling efektif agar peserta didik tetap memiliki antusias atau motivasi yang tinggi selama mengikuti proses belajar mengajar. Suatu pendekatan yang dapat memberikan ruang kepada peserta didik untuk mengekspresikan diri secara mandiri dengan tetap mengedepankan kerjasama antar mereka.

Hasil dari penelitian menunjukkan bahwa penerapan pendekatan project based learning menunjukkan bahwa persepsi mahasiswa terhadap penggunaan pendekatan project based learning adalah positif, mereka antusias ketika pembelajaran menggunakan pendekatan project based learning karena mereka dapat belejar secara mandiri, mereka dapat mengekspresikan ide mereka sehingga kemampuan komunikasi mereka menjadi lebih baik. Mereka juga cenderung melakukan kerjasama dengan teman mereka. Kegiatan dimana peserta didik sebagai student-centred meningkatkan motivasi mereka dalam mengikuti pembelajaran. Peserta didik memiliiki kesempatan untuk presentasi dan menyampaikan hasil proyek yang sudah dikerjakan dengan penuh percaya diri. Pujian dari pendidik bagi mahasiswa yang telah tampil menambah antusias peserta didik meskipun dilaksanakan secara online. Data dari penelitian juga menunjukkan bahwa penerapan pendekatan project based learning mengalami kendala seperti mahalnya kuota yang harus dibeli oleh mahasiswa, jaringan internet yang tidak stabil, dan peserta didik terkadang merasa bosan 
karena harus menatap kamera sepanjang pembelajaran berlangsung.

\section{SIMPULAN DAN SARAN}

\section{A. Simpulan}

Berdasarkan hasil penelitian yang telah dilakukan maka terdapat beberapa kesimpulan yaitu mahasiswa memiliki respon yang positif terhadap penerapan pendekatan project based learning, penggunaan pendekatan project based learning dapat meningkatkan kemampuan mahasiswa dalam kemandirian (autonomous learning), critical thingking, communicative, teamwork, mahasiswa mau mengerjakan tugas yang diberikan oleh dosen. Peserta didik menjadi antusias dalalm mengerjakan proyek yang diberikan sehingga mereka menjadi lebih aktif. Dari nilai juga dapat disimpulkan bahwa penggunaan metode project based learning dapat meningkatkan nilai peserta didik meskipun tidak terlalu signifikan. Disamping kelebihan yang telah dijelaskan diatas, terdapat beberapa faktor yang menjadi kendala dalam penerapan metode project based learning yaitu pengajar dan peserta didik harus melakukan adaptasi terhadap penggunaan project based learning yang dilaksanakan secara online. Pelaksanaa pembelajaran tidak dapat dipantau secara langsung oleh pendidik sehingga peserta didik seringkali tidak fokus pada aktifitas dikelas, fasilitas yang kurang mendukung seperti jaringan yanng kurang stabil, kuota internet yang mahal, dan HP atau komputer yang kualitasnya tidak terlalu baik. Tugas yang terlalu banyak juga menambah beban tersendiri bagi peserta didik. Memori HP atau laptop juga cepat penuh karena harus mendownload materi atau video dalam setiap pertemuan.

\section{B. Saran}

Ada beberapa saran yang peneliti sampaikan untuk peneliti yang lain itu agar memperdalam fokus dari kajian serta di implementasikan untuk sample yang berbeda sehingga dapat memperkaya khasanah dalam penelitian ini. Saran untuk guru agar penggunaan pendekatan ini lebih ditekankan pada berbagai materi dan kemampuan peserta didik. Sementara saran bagi pemangku kepentingan agar lebih fokus pada penyediaan sarana dan prasarana tempat belajar termasuk sumber daya manusia (SDM) para tenaga pengajar agar kualitas pendidikan di Inndonesia terus semakin membaik.

\section{DAFTAR RUJUKAN}

Ary, D., Jacobs, L. C., \& Sorensen, C. (2010). Introduction to Research in Education. Canada: Wadsworth, Cengage Learning.

Creswell, J. W. (2012). Educational Research: Planning, Conducting, and Evaluating Quantitative and Qualitative Research (4th Edition). Boston: Pearson Education, Inc.

Dewi, W. A. F. (2020). Dampak Covid-19 terhadap implementasi pembelajaran daring di Sekolah Dasar. Edukatif: Jurnal Ilmu Pendidikan, 2(1), 55-61.

Fauziati, E. (2014). Methods of Teaching English as a Foreign Language (TEFL). Surakarta: Era Pustaka Utama.

Given, L. M. (2008). The Sage Encyclopedia of Qualitative Research Methods. California: SAGE Publications, Inc.

Isman, Mhd. 2016. Pembelajaran Media dalam Jaringan (Moda Jaringan). The Progressive and Fun Education Seminar, 586.

Richards, J. C. \& Schmidt, R. (2010). Longman Dictionary of Language Teaching and Applied Linguistics (4th edition). London: Pearson Education Limited.

Syah, R, H. (2020) Dampak Covid-19 Pada Pendidikan Di Indonesia: Sekolah Keterampilan, Dan Proses Pembelajaran. Jurnal Sosial Dan Budaya-17 (5). 